\title{
Comparison of ELISA \& Rapid Screening Tests for the Diagnosis of HIV, HBV \& HCV Among Blood Donors in Blood Bank of C.C.M. Medical College Durg Chhatishgarh
}

\author{
Prahlad Chandra Agrawal', Shiv Kumar Chandraker' ${ }^{1}$ and Prarabdha Agrawal² \\ ${ }^{1}$ Dept. of Pathology, Chandulal Chandrakar Memorial Medical College, Durg Chhatishgarh, India \\ ${ }^{2}$ Pandit Jawaharlal Nehru Medical College, Raipur, India
}

\begin{abstract}
Background: HIV,HBV,\& HCV is preventable transmitted disease, can accurately \& correctly analyse by Elisa ,a superior method than rapid screening of blood units \& its components.

Aim: To see the positive results shown by Elisa method is positive by rapid or not. By this the superiority of method can be decided for screening of blood units in blood bank.

Method: Out of 3650 blood units a sample of 50 elisa reactives were retested by Rapid method \& results are analysed \& compared. Only the higher Optical density gives positive result by rapid. Lower Optical density were not detected by rapid method, carry the risk of transmission to recipient.

Result: The result of Elisa is not parallel to rapid test. Many samples reactive by Elisa were not detected positive by rapid due to low OD.

Conclusion: Study shown that Rapid testing of samples for HIV, HBV\& HCV are inferior to Elisa, Which is a gold standard for screening of blood donors in blood banks.
\end{abstract}

Keywords: Transmitted transfusion Diseases, Hepatitis C virus, Prevalence, Blood Units

\section{Introduction}

Blood transfusion services is a life saving vital part of modern health care system(1) worldwide TTIs still remain a major public health problem in many developing countries, mainly due to resourced facility, lack of staff. (2) Blood transmitted infections involves pathogenic viruses are most prominent in transfusion medicine. (3) Screening of blood donors/blood units is done in almost every blood bank facility for viral marker like HIV,HBV \& HCV before the blood units/components are transfused to prevent TTIs. With every units of blood there is $1 \%$ chance of TTIs. Inspite the marked improvement in safety of blood donations, viruses, bacterias remain the most transmitted infection passed on from donor to recipient through transfusion.(4) The greatest risk are donations given in infectious window period (WP), which is the time between the development of infectious viraemia \& reactivity by routine serological or nucleic acid technology(NAT)donor screening test. (5) Blood donors occasionally carry an infectious agent without having any sign \& symptom.(6) Blood transfusion services possess threat to future recipient through blood product. Several screening test/assay have been developed to overcome such threat.These technique are immunochromatographic assay,Enzyme linked immunoabsorbent (Elisa) \& Nucleic acid test(NAT),Polymerase chain reaction(PCR).

Important issue of blood safety is to identify the infectious donors \& to prevent its onward transmission by that safeguarding the recipients. Two strategy is important for its success,one is adaptation of national transfusion policy for selection of donors aims mainly to exclude donors with high risk of infection like HIV,HBV \& HCV, second is the application of method with high specificity \& sensitivity,so as to identify the true positive \& true negative individual/ blood units.(7)

Screening of blood donors are serious issue, if it is not done properly, it leads to serious consequences on blood service. False positive results can leads to larger number of blood donors being deferred, while false negative testing may jeopardize blood safety.(8)

Transfusion of infected blood to individual is a crime. (9) To avoid this strict haemvigilance \& quality control system is necessary for all the blood centres. Mostly 
immunochromatographic rapid test or Elisa test kits are used in blood centre for viral markers.

The primary objective of present study is to retest the sample of Elisa method with Rapid immunochromatographic technique, \& see the sensitivity difference among them.

\section{Material \& Method}

Present study is carried out in the Blood Bank of C.C.M.Medical college Durg C.G. among the 3650 Blood donors attending between 1 april 2016 to 31 march 2017 for the period of one year. The collected blood units were tested for viral markers HIV,HBV \& HCV by Enzyme linked immunoabrbent immunoassay \& immunochromatographic Rapid technique. In our study many reactive sample by Elisa not detected positive by rapid method.

\section{Results}

Figure 1 shows out of 3650 blood units tested for viral markers 50 samples detected Reactive by Elisa. When we retested the Reactive samples with rapid method, there is remarkable difference in sensitivity(Table 1 \& figure 2).

Figure $3 \&$ Table 1 shows out of 50 Reactive samples 10 samples were positive for $\operatorname{HIV}(0.27 \%), 36$ for $\operatorname{HBV}(0.96 \%)$ \& 4 Samples $(0.10 \%)$ for HCV infection. From Figure 4 By rapid method of 10 cases of HIV reactive by Elisa only 6 cases shows positive $(60 \%)$ result, remaining 4 cases $(40 \%)$ were lower optical density not detected positive. In case of HBV out of 36 cases, only 28 cases $(77.7 \%)$ positive by rapid method, \& 8 cases $(22.2 \%)$ not detected positive. For HCV out of 4 cases, 2 cases Positive (50\%) \& 2 cases $(50 \%)$ negative by rapid screening.

Table 1 OD OF HIV.

\begin{tabular}{|c|c|c|c|c|c|}
\hline \multirow{2}{*}{ Serial No. } & \multirow{2}{*}{ Cut of value } & \multicolumn{2}{|c|}{ Optical density } & \multicolumn{2}{|c|}{ Result } \\
\hline & & Positive Control & Test & Elisa & Rapid \\
\hline 1 & 0.1404 & 1.6976 & 1.9885 & + & + \\
\hline 2 & 0.1325 & 2.4706 & 0.2400 & + & - \\
\hline 3 & 0.1325 & 2.4706 & 0.17 & + & - \\
\hline 4 & 0.1325 & 2.4706 & 0.22 & + & - \\
\hline 5 & 0.1325 & 2.4706 & 1.90 & + & + \\
\hline 6 & 0.1585 & 1.1762 & 0.53 & + & + \\
\hline 7 & 0.1707 & 1.2222 & 0.17 & + & - \\
\hline 8 & 0.1707 & 1.2222 & 0.36 & + & + \\
\hline 9 & 0.1745 & 1.307 & 0.53 & + & + \\
\hline 10 & 0.1358 & 2.329 & 2.63 & + & + \\
\hline
\end{tabular}

\section{OD OF HBV}

\begin{tabular}{|c|c|c|c|c|c|}
\hline \multirow{2}{*}{ Serial No. } & \multirow{2}{*}{ Cut of value } & \multicolumn{2}{|c|}{ Optical Density } & \multicolumn{2}{|c|}{ Result } \\
\hline & & Positive Control & Test & Elisa & Rapid \\
\hline 1 & 0.2068 & 3.467 & 3.500 & + & + \\
\hline 2 & 0.2068 & 3.467 & 1.27 & + & + \\
\hline 3 & 0.2026 & 2.6320 & 0.94 & + & + \\
\hline 4 & 0.2239 & 2.9599 & 0.95 & + & + \\
\hline 5 & 0.1761 & 3.1917 & 3.20 & + & + \\
\hline 6 & 0.2041 & 2.7519 & 3.20 & + & + \\
\hline 7 & 0.1957 & 3.4574 & 2.85 & + & + \\
\hline 8 & 0.1996 & 3.2748 & 2.96 & + & + \\
\hline 9 & 0.1904 & 3.4442 & 0.21 & + & - \\
\hline 10 & 0.1928 & 3.2641 & 3.55 & + & + \\
\hline 11 & 0.1928 & 3.2641 & 0.31 & + & - \\
\hline 12 & 0.1928 & 3.2641 & 0.20 & + & - \\
\hline
\end{tabular}




\begin{tabular}{|c|c|c|c|c|c|}
\hline \multirow{2}{*}{ Serial No. } & \multirow{2}{*}{ Cut of value } & \multicolumn{2}{|c|}{ Optical Density } & \multicolumn{2}{|c|}{ Result } \\
\hline & & Positive Control & Test & Elisa & Rapid \\
\hline 13 & 0.2355 & 3.0186 & 3.47 & + & + \\
\hline 14 & 0.2355 & 3.0186 & 0.76 & + & - \\
\hline 15 & 0.2162 & 2.9471 & 0.22 & + & - \\
\hline 16 & 0.1849 & 3.1171 & 4.32 & + & + \\
\hline 17 & 0.1796 & 3.3759 & 3.88 & + & + \\
\hline 18 & 0.1796 & 3.3759 & 3.33 & + & + \\
\hline 19 & 0.1849 & 3.4998 & 4.35 & + & + \\
\hline 29 & 0.1953 & 3.4777 & 3.26 & + & + \\
\hline 30 & 0.1953 & 3.4777 & 3.79 & + & + \\
\hline 31 & 0.2063 & 2.9479 & 0.28 & + & - \\
\hline 32 & 0.1926 & 3.3030 & 3.18 & + & + \\
\hline 33 & 0.1751 & 3.3333 & 2.28 & + & + \\
\hline 34 & 0.1888 & 3.2020 & 2.19 & + & + \\
\hline 35 & 0.1966 & 3.2111 & 0.20 & + & - \\
\hline 36 & 0.2084 & 2.9719 & 0.21 & + & - \\
\hline
\end{tabular}

OD OF HCV

\begin{tabular}{|c|c|c|c|c|c|}
\multirow{2}{*}{ Serial No. } & Cut of value & \multicolumn{2}{|c|}{ Optical Density } & \multicolumn{2}{|c|}{ Result } \\
\cline { 3 - 6 } & & Positive Control & Test & + & + \\
\hline 1 & 0.3519 & 2.5767 & 1.45 & + & + \\
\hline 2 & 0.3128 & 2.4831 & 0.32 & + & + \\
\hline 3 & 0.3253 & 2.4055 & 1.07 & + & + \\
\hline 4 & 0.3263 & 2.4744 & 0.43 & + \\
\hline
\end{tabular}

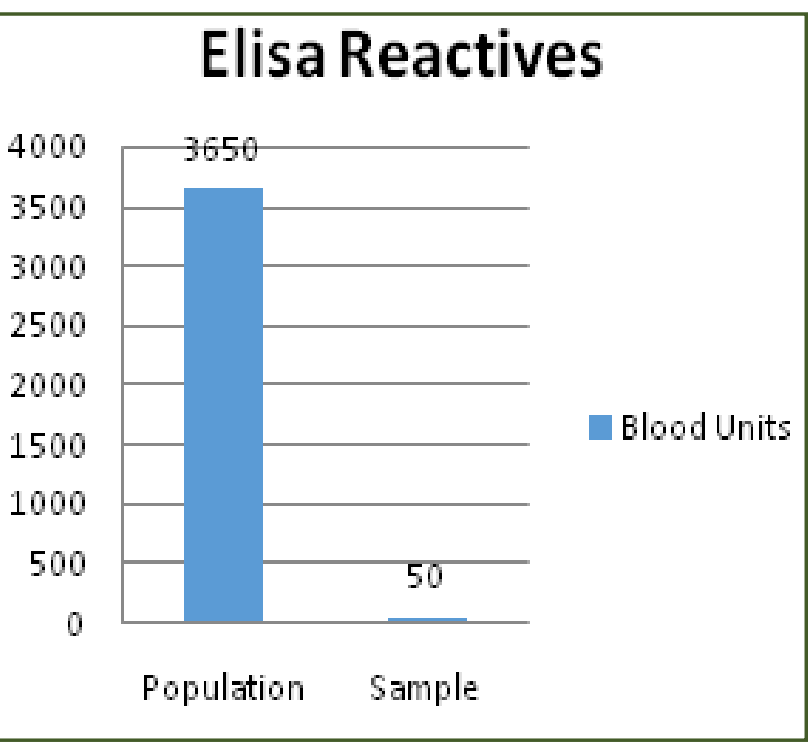

Fig. 1

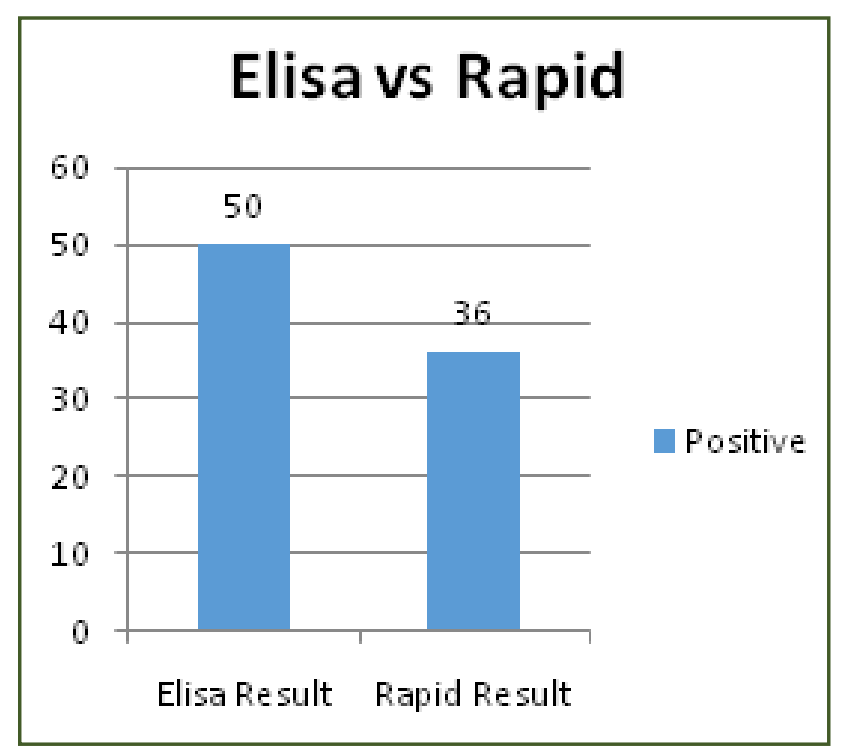

Fig. 2 


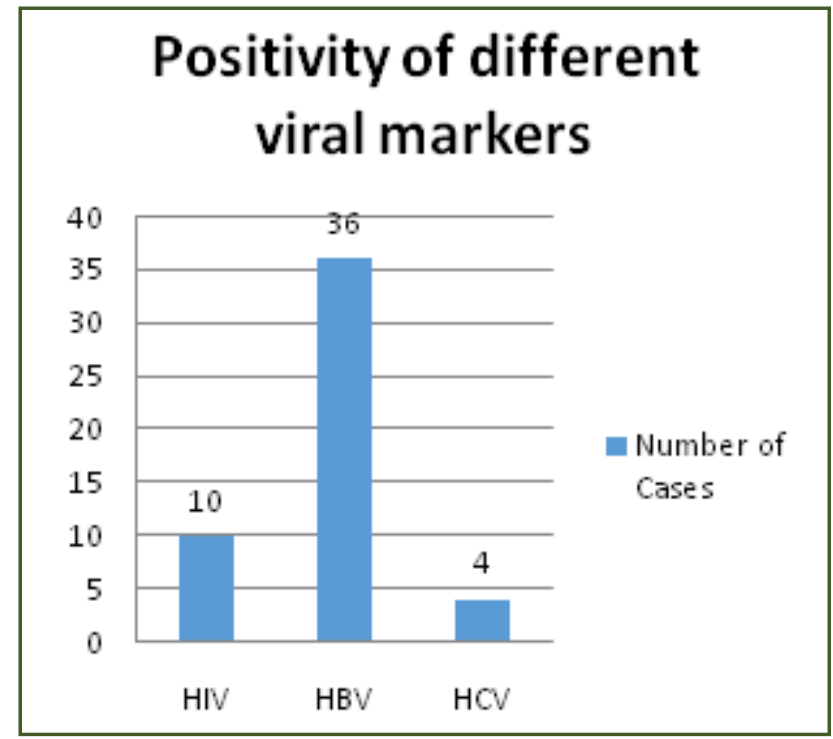

Fig. 3

\section{Discussion}

TTIs are the common serious problem of blood transfusion. In developed countries very low rate of transmission of TTIs has been achieved by avoiding unnecessary transfusion, using only regular voluntary donors, systematic screening of donors for infections by high sensitive assay method like Elisa \& availability of NAT.(10) Glynn et al reported that introduction of NAT in blood donors decreased the risk of HCV \& HIV significantly.(11)

If these interventions are applied uniformly the risk of TTIs remains low. Recently blood banks in India are trying these interventions for improved safety, but NAT not available in most parts of India including Chhattisgarh because of unaffordibility of the test.(12)

Seroprevalance of TTIs in his study was 50/3650(1.37\%), this comparable to other studies by Teoks et al (1.49\%)(13), saghir et al (2.35\%)(14) Abdullah \& Ali et al (3\%)(15)

The NACO has reported the overall prevalence of HIV of $0.36 \%$ (2006 estimate) in India. In our study almost similar value is found.

Seroprevalance of HIV in Indian studies reported to range between $0.2-1 \%$ (16 17) overall seroprevalance of HIV in our study was $0.27 \%$,(Table 1 \& Figure 3 ) which is similar to other studies in India.

WHO placed India in the intermediate zone for HBV. The seroprevalance of HBV in our study was $0.96 \%$.(Table 1 \& Figure 3) In India it ranges between 0.86-4\% (18 19). Seroprevalance of Pakistan (20) \& Bangladesh is reported as (range $1.55-8.4 \%$ ) \& (range $1.5-2.96 \%$ )

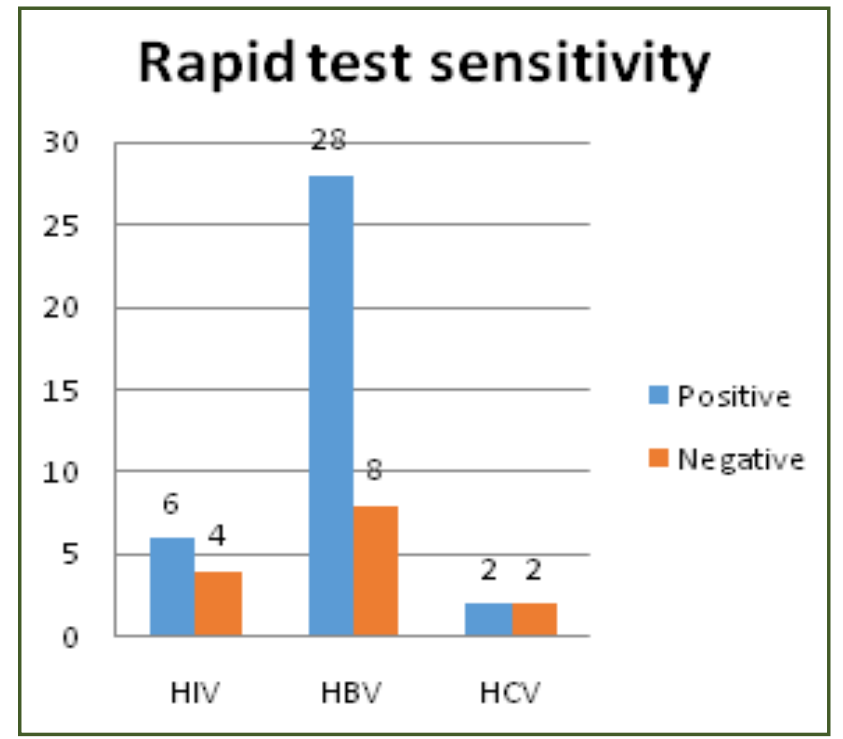

Fig. 4

Prevalence of HCV in India studies ranges between 0.4$1.09 \%$. Studies done in Pakistan (18 19) \& Bangladesh (20) reported HCV prevalence range $0.07-4.9 \%$ \& $0.13-$ $4.3 \%$. Overall seroprevalance of $\mathrm{HCV}$ in our blood bank was $0.10 \%$ ( Table $1 \&$ Figure 3 )

When we compare the result of Elisa with rapid test, a dramatic outcome is achieved. For HIV(Table 1 \& Figure 3 ) out of 10 cases 6 cases shown reactive by Elisa have high optical density above 0.53 , as compare to 4 cases in which OD was 0.24 (cov was $0.13-0.17$ ). so marginal rise in OD is not detected by rapid method. This shows lower sensitivity of rapid test as compare to Elisa .

In cases of HBV(Table 1\& Figure 3) 36 cases reported reactive by elisa, only 28 cases have optical density above 0.76 to 2.85 ( cov $0.17-0.23$ ), given positive result $(77.7 \%)$ as compare to 8 cases $(22.2 \%)$ have optical density up to 0.76 (ranges $0.20-0.76$ ) not detected positive.

For HCV(Table $1 \&$ Figure 3 ) out of 4 cases 50\% shown positive \& 50\% shown negative by rapid technique. Optical density above 1.07 given reactive whereas optical density below 0.43 detected negative by rapid test.

\section{Conclusion}

This study showed remarkable sensitivity difference between both the method. For HIV 40\%( 4 cases out of 10 ), HBV $22.2 \%$ (8 cases out of 36 ) \& for HCV $50 \%$ (2 out of 4 cases) were not detected by Rapid method(Table $1 \&$ Figure 4). This lower sensitivity method is unsuitable $\&$ is inferior in quality testing of infectious markers in blood donors in blood bank as screening. So the Rapid method are not recommended in transfusion centre for screening of donors. 


\section{References}

1. Transfusion medicine. Technical manual, 2 nd ed. WHO; 2003. p. 151

2. Aach RD, Szmuness W, Mosley JW, Hollinger FB, Kahn RA, Stevens CE, et al. Serum alanine aminotransferase of donors in relation to the risk of non-A,non-B hepatitis in recipients: the transfusion-transmitted viruses study. N Engl J Med. 1981; 304(17):989-94. PubMed | Google Scholar

3. Niederhauser C, Schneider P, Fopp M, Ruefer A, Levy G. Incidence of viral markers and evaluation of the estimated risk in the Swiss blood donor population from 1996 to 2003. Euro Surveill. 2005; 10(2):14-6. PubMed | Google Scholar

4. El-Sherif AM, Abou-Shady MA, Al-Hiatmy MA, AlBahrawy AM, Motawea EA. Screening for hepatitis B virus infection in Egyptian blood donors negative for hepatitis B surface antigen. Hepatol Int. 2007; 1(4):46970. PubMed | Google Scholar

5. Busch MP, Glynn SA, Stramer SL, Strong DM, Caglioti S, Wright DJ, et al. A new strategy for estimating risks of transfusion-transmitted viral infections based on rates of detection of recently infected donors. Transfusion. 2005;45(2):254-64. PubMed | Google Scholar

6. McClelland DBL. Handbook of transfusion medicine : blood transfusion services of the United Kingdom. 2nd ed ed London: HMSO.1996. Google Scholar

7. Basavaraju SV, Mwangi J, Nyamongo J, Zeh C, Kimani D, Shiraishi RW, et al. Reduced risk of transfusion-transmitted HIV in Kenya through centrally co-ordinated blood centres, stringent donor selection and effective p24 antigenHIV antibody screening. Vox Sang. 2010; 99(3):2129. PubMed | Google Scholar

8. Rahman M, Khan SA, Lodhi Y. Unconfirmed reactive screening tests and their impact on donor management. Pak J Med Sci. 2008; 24(4):517-19. PubMed | Google Scholar

9. Torane VP, Shastri JS. Comparison of ELISA and rapid screening tests for the diagnosis of HIV, Hepatitis B and Hepatitis $\mathrm{C}$ among healthy blood donors in a tertiary care hospital in Mumbai. Indian J Med Microbiol. 2008; 26(3):284-5. PubMed | Google Scholar

10. Lathamani K., Bhaktha G, Nayak S.,Kotigadde S. Prevalence of HIV, HCV,HBV and Syphilis in Blood donors among the Dakshina Kannada District, India Int.J.Curr.Microbiol.App. Sci (2013) 2(10):249-252
11. Glynn SA, Kleinman SH, Wright DJ, Bush MP. For the NHLBI retrovirus epidemiology donor study: International application of incidence rate/ window period model. Transfusion 2002; 42: 966-72

12. Shah N, Shah J.M., Jhaveri P, Patel K, Shah C.K., Shah N.R. Sero prevalence of HBV, HCV, HIV and syphilis among blood donors at a tertiary Care Teaching Hospital in Western India GUJARAT MEDICAL JOURNAL ,2013; 68: 3539

13. Sharma RR, Cheema R, Vajpayee M, Rao U, Kumar S, Marwaha N, et al. Prevalance of markers of transfusion transmissible diseases in voluntary and replacement blood donors. The national medical journal of India 2004; 171: 19 -21 .

14. Paramjit K, Basu S. Transfusion transmitted infections: Existing and emerging pathogens. Journal of post graduate medicine 2005;51:146-51.

15. World health organization South-East Asia Regional Office. Prevention of hepatitis B in India-an overview. Available from: whqlibdoc.who.int/searo/2002/SEA_Hepat .-5.pdf, accessed on June 10, 2014

16. Chandrasekaran S, Palaniappan N, Krishnan V, Mohan G, Chandrasekaran N. Relative prevalence of hepatitis B viral markers and hepatitis $\mathrm{C}$ virus antibodies (Anti $\mathrm{HCV}$ ) in Madurai, South India Indian journal of medical sciences 2000;547:270-73

17. Khan MA, Rehaman A, Ashraf M, Ali A, Detta A. Prevalance of HPV, HCV and HIV in blood donors at Liaquatpur. Professional med j 2006;13:23-26.

18. Khan Z, Raziq F, Aslam N. Prevalance of HIV in blood doors in NWFP. J Postgradmed inst 2002;16:187-89.

19. Saha SK, Banik RK, Saha MR, Habibullah MM, Mahtab MA. Prevalance of transfusion transmitted infectio in healthy blood donors in sir Salimullah medical college Dhaka, Bangladesh. Euroasianjournals of hepatogastroenterology,2011;1:68-70.

20. Saha SK, Banik RK, Saha MR, Habibullah MM, Mahtab MA. Prevalance of transfusion transmitted infectio in healthy blood donors in sir Salimullah medical college Dhaka, Bangladesh. Euroasian journals of hepato-gastroenterology, 2011;1:68-70.

*Corresponding author:

Dr Prahlad Chandra Agrawal, Dept. of Pathology, Chandulal Chandrakar Memorial Medical College, Durg Chhatishgarh, India Phone: +919425212528

Email: drpcagrawal206@gmail.com

Date of Submission : 30.03.2017

Date of Acceptance : 08.04.2017

Financial or other Competing Interests: None.

Date of Publication : 11.04.2017 